\title{
Prof. F.N. Lion-Cachet
}

Die Redaksie van In die Skriflig het besluit om hierdie uitgawe van die tydskrif op te dra aan prof. F.N. Lion-Cachet, wat aan die einde van 1996 na ses en twintig en 'n half jaar aan die Teologiese Skool en die PU vir $\mathrm{CHO}$ geëmeriteer het. Hy was en is steeds 'n gewaardeerde kollega wat op baie terreine 'n besondere bydrae gelewer het. Op hierdie manier wil die Redaksie sê: baie dankie vir hierdie bydrae. Dat sy optrede en bydrae erkenning geniet het, blyk uit die verskeidenheid van kollegas wat 'n bydrae tot hierdie bundel gelewer het.

Hy is op 23 Mei 1931 in Nigel gebore en het in 1948 aan die Hoër Volkskool te Heidelberg (Transvaal) gematrikuleer. Hy begin sy studies in 1949 aan die Universiteit van die Witswatersrand waar hy in die ingenieurswese wou studeer. In dieselfde jaar gaan hy egter na die PU vir CHO en begin sy teologiese studies, waar hy die volgende grade behaal het:

\section{B.A. 1952}

B.A. Hons 1954 (Semitiese Tale)

M.A. 1964 (Semitiese Tale)

Th.B. 1956

Theologiae Doctor 1977, met 'n proefskrif: "Die kontinuiteit van die Abrahamitiese verbond in die opset van die Sinaitiese verbond".

As predikant het hy in die volgende Gereformeerde Kerke gedien:

$$
\begin{array}{ll}
1956-1963 & \text { Pietersburg } \\
1963-1967 & \text { Leslie/Eendracht } \\
1967-1970 & \text { Heidelberg (Tvl) }
\end{array}
$$

In 1970 is hy beroep na die Teologiese Skool Potchefstroom en die PU vir CHO. In 1974 word hy professor in Ou Testament. Van 1979-1981 was hy hoof van die Departement Bybelkunde aan PU vir CHO en van 1990-1996 hoof van Departement Ou en Nuwe Testament. Hy het van 1988-1991 gedien as Adjunkdekaan van Fakulteit Teologie en van 1992-1994 as Dekaan. Van 19881994 was hy ook Viserektor van die Teologiese Skool.

Hy is getroud met Wiida Geertsema en hulle het vyf kinders. Hulle kinders en kleinkinders is steeds vir hulle ' $n$ besondere vreugde.

Sy werk in die vakgebied van die Ou Testament was en is steeds vir hom 'n meer as net 'n werk. Hy is 'n uitnemende dosent en sy klasse was altyd inspirerend, soos ek self kan getuig. Onderrigvernuwing was vir hom 'n leefwyse en hy het altyd op hoogte gebly van nuwe ontwikkelinge op sy vakgebied wat onderrigmetodologie betref. Sy bydrae ten opsigte van die ontwikkelinge van 
nuwe programme in die onderrig en sy gebruikmaking van goeie hulpmiddels is ' $n$ voorbeeld wat ons ander probeer navolg het. Vir drie en twintig jaar was hy en prof. J.L. Helberg kollegas op Potchefstroom en het hulle 'n blywende stempel afgedruk - en het hul ook 'n voorbeeld van hartelike samwerking gestel.

Hy was 'n goeie navorser wat baie artikels en ander publikasies die lig laat sien het. Hy het voordragte gelewer by konferensies in Suid-Afrika en in die buiteland. Soos enige akademikus het hy sy eie benadering en sy eie standpunte gehad. Hy was egter altyd oop om na ander standpunte te luister en om ander hulle standpunte te gun. Belangrike publikasies oor verskeie aspekte van die Ou Testament het van sy pen verskyn. Hierin het hy gehandel oor die besondere kanoniek (Boek en boodskap, 1982) en eksegese (In die werkswinkel van die OuTestamentiese eksegese, 1987). In die meer onlangse verlede het hy hom besonder toegespits op navorsing op die Pentateug. Benewens talle artikels wat verskyn het, verdien sy boek So het dit begin: Gods boodskap in die raamwerk van die historiese boeke van die Ou Testament (1989), besondere vermelding. Hy het 'n nuwe beklemtoning in die studie van die Pentateug in ons kring gebring waarin hy rekening hou met die ontwikkelingsgeskiedenis van die Pentateug. Veral sy bestudering van die wettebundels teen die agtergrond van verskillende tye is besonder insiggewend.

Tans is hy nog steeds betrokke by onderrig en navorsing en ons sien steeds uit na die bydrae wat hy lewer. Hy is 'n begaafde en kunssinnige mens en 'n lojale vriend. Sy bydrae sal lank onthou en waardeer word. Mag hy en Wiida steeds God se genade op 'n besondere wyse ervaar en mag hulle lank vir hulle kinders, kollegas en vriende gespaar bly.

\section{Herrie van Rooy}

Departement Ou en Nuwe Testament Potchefstroomse Universiteit vir $\mathrm{CHO}$ 